\title{
Benthos and demersal fish habitats in the German Exclusive Economic Zone (EEZ) of the North Sea
}

\author{
Hermann Neumann - Henning Reiss • Siegfried Ehrich • \\ Anne Sell · Kay Panten • Matthias Kloppmann • \\ Ingo Wilhelms $\cdot$ Ingrid Kröncke
}

Received: 30 January 2012/Revised: 26 September 2012/ Accepted: 1 October 2012/Published online: 31 October 2012

(C) Springer-Verlag Berlin Heidelberg and AWI 2012

\begin{abstract}
We compiled data from different monitoring surveys to analyse and compare community and diversity patterns of fish, epi- and infauna in the German Exclusive Economic Zone (EEZ) of the North Sea in order to identify benthic habitats common to all faunal components. We found congruent community patterns of fish, epi- and infauna for the coastal waters, the Oysterground and the area called "Duck's Bill", which coincided with specific abiotic characteristics of these regions. The three regions were defined as special habitats for fish, epi- and infauna species in the German EEZ. The differences in the seasonal variability of abiotic factors seem to be the most important discriminating abiotic characteristic for the three habitats. The spatial distribution of fish, epifauna and infauna communities remained stable over time although habitat characteristics such as sea surface temperature increased due to climate change. However, it is expected that the coastal habitat will be more sensitive to future climate
\end{abstract}

Communicated by A. Malzahn.

Electronic supplementary material The online version of this article (doi:10.1007/s10152-012-0334-z) contains supplementary material, which is available to authorized users.

H. Neumann $(\bowtie) \cdot$ H. Reiss · I. Kröncke

Marine Research Department, Senckenberg am Meer,

Südstrand 40, 26382 Wilhelmshaven, Germany

e-mail: hneumann@senckenberg.de

H. Reiss

Faculty of Biosciences and Aquaculture, University of Nordland, PO box 1490, 8049 Bod $\varnothing$, Norway

S. Ehrich · A. Sell · K. Panten · M. Kloppmann · I. Wilhelms Johann Heinrich von Thünen Institute, Institute of Sea Fisheries, Palmaille 9, 22767 Hamburg, Germany change effects in contrast to the Oysterground and Duck's Bill habitat.

Keywords Epifauna $\cdot$ Infauna $\cdot$ Demersal fish $\cdot$ Spatial distribution · Community structure · Habitat stability · Climate change

\section{Introduction}

Analysing spatial patterns of species communities has a long tradition in North Sea research. First spatial investigations of benthic infauna communities were carried out by Petersen (1914) in Danish waters, while first studies on spatial patterns of benthic epifauna were conducted by Dyer et al. (1982, 1983) resulting from the analysis of fisheries' bycatch. Daan et al. (1990) highlighted the importance to analyse fish communities instead of single commercial species to understand how the North Sea ecosystem functions. Since the beginning of such investigations, effort increased to analyse spatial community structure of fish (Greenstreet and Hall 1996; Ehrich et al. 2009), benthic infauna (Duineveld et al. 1991; Heip et al. 1992; Künitzer et al. 1992; Kröncke et al. 2011) and benthic epifauna (Frauenheim et al. 1989; Jennings et al. 1999; Zühlke et al. 2001) on a North Sea wide scale. However, similarities and the interrelationships in community structure between these faunal components were only recently studied, for example by Callaway et al. (2002) and Reiss et al. (2010). Most of these studies have identified the 50-m depth contour in the North Sea as a conspicuous boundary separating fish, epifauna and infauna communities since it closely matches the boundary between mixed and stratified waters and is, thus, related to abrupt changes in the abiotic environment. Additionally, epifauna and infauna diversity 
was found to be lower in the southern North Sea than in central and northern parts, while conversely fish diversity was highest near the major inflows of Atlantic water masses in the North Sea (Fair Isle, East Shetland and English Channel) (Callaway et al. 2002; Reiss et al. 2010).

Spatial boundaries for ecosystem management, nature conservation and spatial planning are in most cases represented by the Exclusive Economic Zones (EEZ) of the different North Sea neighbouring states. Within the German EEZ, limited attention has been paid to the interrelationships in community structure and diversity of different faunal components. Additionally, the spatial resolution of large-scale studies was often not sufficient to meet national management requirements. Callaway et al. (2002), for instance, only defined two epifauna communities and one fish community by analysing approximately 10 stations in the area of the German EEZ. Reiss et al. (2010) found three epifauna and two fish communities based on 25 stations. Epifauna community structure in and around the German EEZ was analysed by Neumann et al. (2009), but also on limited sampling resolution. The most detailed studies dealing with community structure of benthic infauna in the German EEZ were carried out by Salzwedel et al. (1985) and Rachor and Nehmer (2003). Rachor and Nehmer (2003) defined eight benthic regions in the German EEZ of the North Sea based on infauna community structure, which they also related to the presence and absence of epifauna species.

However, a comprehensive analysis of the interrelationships in community structure between fish, epifauna and infauna as well as underlying environmental drivers in the German EEZ is missing and, thus, a detailed description of habitats in the EEZ, which were defined here as "a particular environment which can be distinguished by its abiotic characteristics and associated biological communities at particular but dynamic scales of space and time in a specific geographic area" (sensu ICES 2006; Kearney 2006). Additionally, a single sampling gear as used in most studies is insufficient to sample the whole species inventory of habitats in the EEZ since catchability greatly differs between gears (Reiss et al. 2006a; Ehrich et al. 2007). International directives and policies such as the Habitat Directive (HD) and the Marine Strategy Framework Directive (MSFD) require the development of a favourable condition of habitats and species (Commission 1992, 2008). However, the lack of knowledge and data especially with regard to the benthos is often recognized in the implementation of such directives (BMU 2012). To provide some more baseline information in this context, data taken during surveys of the "International Bottom Trawl Survey (IBTS)", the "German Autumn Survey in the Exclusive Economic Zone (GASEEZ)" and the German data of the "ICES North Sea Benthos Project 2000" were compiled and analysed (1) to describe community structures and diversity of fish, benthic epifauna and infauna in the German EEZ and (2) to identify congruent patterns between faunal components. Finally, we relate common community and diversity patterns to abiotic characteristics (3) to classify habitats in the German EEZ for all faunal components.

\section{Materials and methods}

\section{Area of investigation}

Samples were taken in the German Exclusive Economic Zone (EEZ) of the North Sea, which stretches from the seaward edge of the German territorial coastal waters (12 mile zone) out to approximately 170 nautical miles away from it covering an area of approximately $28,600 \mathrm{~km}^{2}$. The study area includes the German Bight in the south as well as parts of the eastern Dogger Bank and the central North Sea in the north (Duck's Bill). The depth generally increase from the coast (approx. $15 \mathrm{~m}$ ) towards the central North Sea (approx. $60 \mathrm{~m}$ ) with exception of the Dogger Bank, where station depths is about $30 \mathrm{~m}$ and the post-glacial valley of the river Elbe in the south, where station depth exceed $40 \mathrm{~m}$. Sediments in the German EEZ generally consists of fine sand. Mud content is highest in the inner German Bight (up to $40 \%$ ) and lowest at the Dogger Bank and along the North Frisian coast (Fig. 6b). Coarser sediments occur only locally in areas such as the "Borkum Riffgrund", "Amrum Bank" or the "Helgoländer Steingrund".

\section{Data and data processing}

Species abundance of three datasets for fish, two for benthic epifauna and one for benthic infauna dataset were used to analyse community structure of the three faunal components in the German EEZ.

Fish was sampled with a 7-m beam trawl (B7) at 75 stations in late autumn 2009 as well as at 66 stations in late autumn 2010 by using a cod trawl (CT) both during the "German Autumn Survey in the Exclusive Economic Zone (GASEEZ)" with the RV Solea. Both gears were equipped with a codend liner of $20-\mathrm{mm}$ mesh opening. The standard towing time was $30 \mathrm{~min}$ for the cod trawl and $15 \mathrm{~min}$ for the 7-m beam trawl at a target speed of 3.5-4 knots over ground. Abundance data of 32 species (B7) and 34 species (CT) were used for the analyses standardized to the allocated tow duration. In addition, abundance data of fish caught by a 2-m beam trawl (B2) at 52 stations during the third quarter "International Bottom Trawl Survey (IBTS)" in summer 1999 and 2000 were analysed. The 2-m beam 
trawl was fitted with a 20-mm net and a codend liner of 4-mm mesh size and towed at 1-2 knots for $5 \mathrm{~min}$. A depth probe was attached to the beam trawl to determine the time and position of contact with the seabed. 2-m beam trawl data were standardized to a sampled area of $500 \mathrm{~m}^{2}$. Twenty-four fish species were included in the analysis. Pelagic fishes were excluded from all datasets.

Benthic epifauna data were taken from 2- and 7-m beam trawl hauls within the IBTS in 1999 and 2000 (57 species) and the GASEEZ in 2009 (62 species) (see fish data for gear description). The 2-m beam trawl samples were sieved over $5-\mathrm{mm}$ mesh size, and the epifauna were separated from the remains. Most species were identified on board, while unidentified species were preserved in $4 \%$ buffered formalin for identification in the laboratory. Epifauna from the 7-m beam trawl were directly identified and counted from the fisheries hauls on board of the RV Solea. Data were standardized to $500 \mathrm{~m}^{2}$ towed area (2-m beam trawl) and $15 \mathrm{~min}$ (7-m beam trawl), respectively. Generally, colonial species as well as infauna species were omitted from analyses, but the bivalves Euspira pulchella and Nucula nitidosa as well as the snail Corbula gibba were included in the 2-m beam trawl dataset since they were caught regularly due to the small codend liner of the trawl.

Benthic infauna data were taken from the "ICES North Sea Benthos Project 2000" dataset (Rees et al. 2007) consisting of 321 infauna species from 190 stations in the German EEZ sampled in 2000 and based on Rachor and Nehmer (2003). Sampling was carried out by collecting infauna with a $0.1-\mathrm{m}^{2}$ van Veen grab, sieving over $1-\mathrm{mm}$ mesh size and preserving the material in $4 \%$ buffered formalin for identification in the home laboratories. All data were standardized to $1 \mathrm{~m}^{2}$. For a detailed description of sampling methods, see Rees et al. (2007).

Sediment (mud; $<63 \mu \mathrm{m}$ sieve fraction) as well as winter (December-February) and summer (June-August) bottom temperature data of the German EEZ were taken from the Senckenberg sediment database and the temperature database of the vTI-Institute of Sea Fisheries covering a period from 1998 to 2008.

\section{Data analyses}

Hierarchical cluster analysis and non-metric multidimensional scaling (MDS) in the PRIMER version 6 package (Plymouth Marine Laboratory) were used to separate groups of stations with similar community structure based on square-root- (fish) and fourth-root (benthic epi- and infauna)-transformed abundance data. Fourth-root transformation for benthic fauna was used to minimize the influence of dominant species, which was not necessary for fish data. SIMPROF test and an average similarity of at least $40 \%$ were used as criteria for defining groups with similar community structure. SIMPROF is a permutation test looking for statistical significance of clusters in samples which are not a priori divided into groups (contrary to ANOSIM; see below). The PRIMER program SIMPER was used to identify species predominantly responsible for the similarity within groups. Similarities were calculated using the Bray-Curtis coefficient. ANOSIM randomization tests were performed to test the differences in community structure between the areas in the German EEZ $\left(H_{0}=\right.$ no differences in community structure). RELATE analyses within the PRIMER package were used to test similarity between the community structures of different faunal components and gears, respectively, based on the corresponding similarity matrices. Diversity was assessed by calculating species number and Shannon-Wiener Index $\left(\mathrm{H}^{\prime}\right)$ which both were given as mean values of the corresponding community. Inverse distance weighted interpolation in ArcGIS 10 was used for mapping species number, sediments as well as late autumn/winter and summer bottom temperature in the German EEZ.

\section{Results}

In total, 53 demersal fish species (cod trawl, 7- and 2-m beam trawl), 93 epifauna species (7- and 2-m beam trawl) and 321 infauna species $\left(0.1-\mathrm{m}^{2}\right.$ van Veen grab) were recorded and analysed.

\section{Community structure}

Fish was sampled with a 2- and 7-m beam trawl as well as a cod trawl, and corresponding communities in the EEZ are shown in Fig. 1a, c, e. ANOSIM randomization test revealed significant differences between all five communities identified $(R=0.59-0.83 ; p<0.001)$. Similarity within clusters varied from 40 to $71 \%$. Two clear coastal communities were obvious for fish caught with the 7-m beam trawl but not for the other gears. Characteristic species predominantly found at the coast with the 7-m beam trawl were the goby Pomatoschistus spp. (Fig. 2a; Table 1), the hooknose Agonus cataphractus (Fig. 2b) or the sea snail Liparis liparis (Appendix 2, ESM), but also widespread species such as the dab Limanda limanda were counted among the dominant coastal species (Table 1). Similar species but in different abundances were characteristic for the transitional communities between the coast and the Oysterground, which were generally found for all gears. In contrast, the solenette Buglossidium luteum was frequently caught with the 2- and 7-m beam trawl only (Fig. 3a; Appendix 2, ESM). An Oysterground community resulted from the cod trawl and 7-m beam trawl hauls. The grey gurnard Eutrigla gurnardus was characteristic for the Duck's Bill region and was 


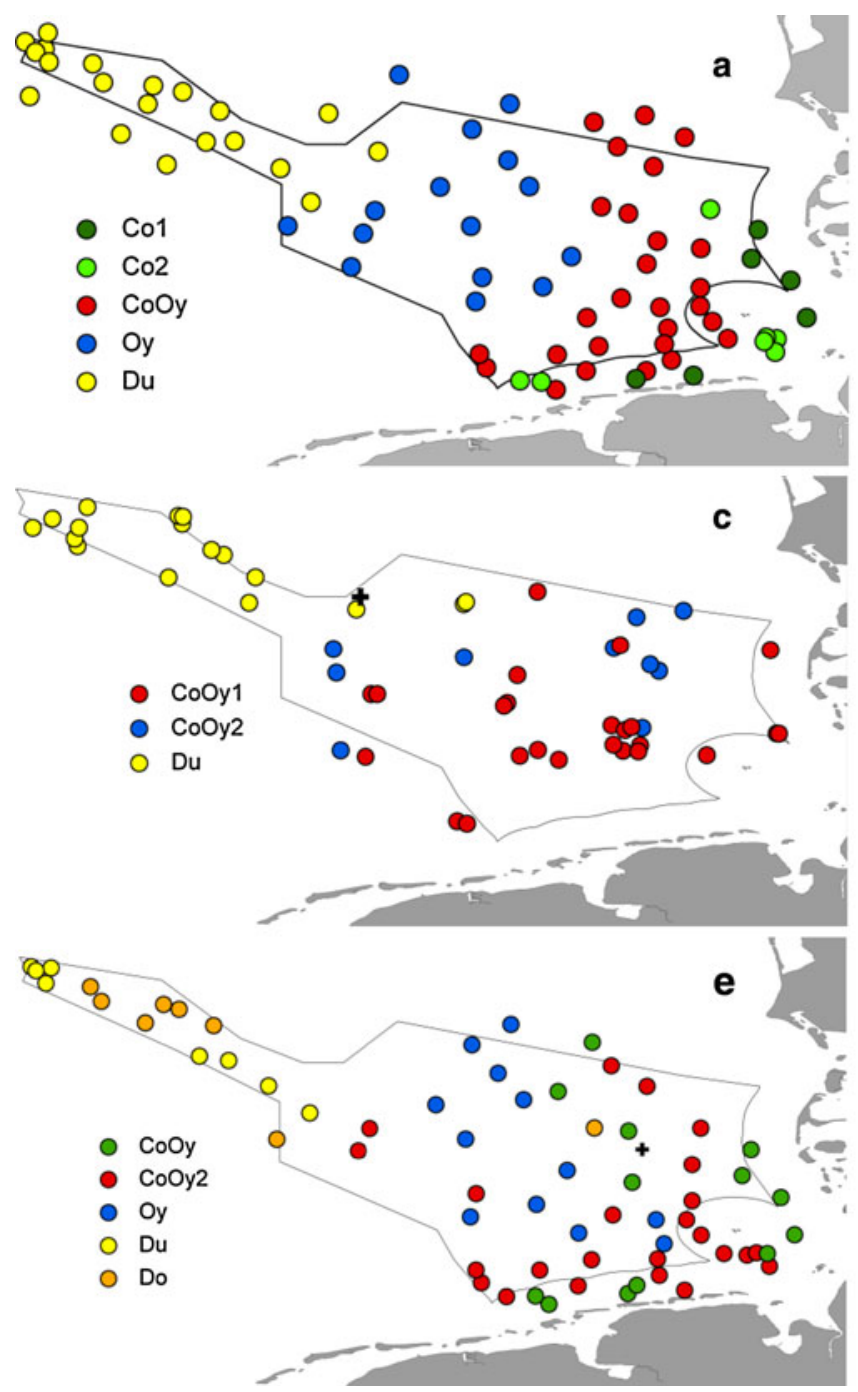

Fig. 1 Fish (a, c, e), epifauna (b, d) and infauna (f) communities in the German EEZ sampled with 7-m beam trawl $(\mathbf{a}, \mathbf{b}), 2-\mathrm{m}$ beam trawl (c, d), cod trawl (e) and $0.1-\mathrm{m}^{2}$ van Veen grab (f). (Co coast, $O y$

predominantly caught with the cod trawl and the 7-m beam trawl (Fig. 4b). A Dogger Bank community was obvious in the cod trawl for the dab L. limanda, the whiting Merlangius merlangus and the gurnard E. gurnardus as characteristic species. These species occurred also in the adjacent Duck's Bill community, but in lower abundances (Table 1; Appendix 2-4, ESM).

Epifauna analyses were carried out with 7- and 2-m beam trawl data (Fig. 1b, d). All clusters found were significantly different (ANOSIM; $R=0.70$ and 0.87; $p<0.001$ ) with an average similarity within clusters between 50 and $71 \%$. Analyses revealed clearly separated communities at the coast dominated by very high abundances of common German Bight species such as the seastar Asterias rubens (Fig. 2d), the swimming crab Liocarcinus holsatus (Fig. 2c), the shrimp Crangon crangon or the brittle star Ophiura albida (Table 1; Appendix

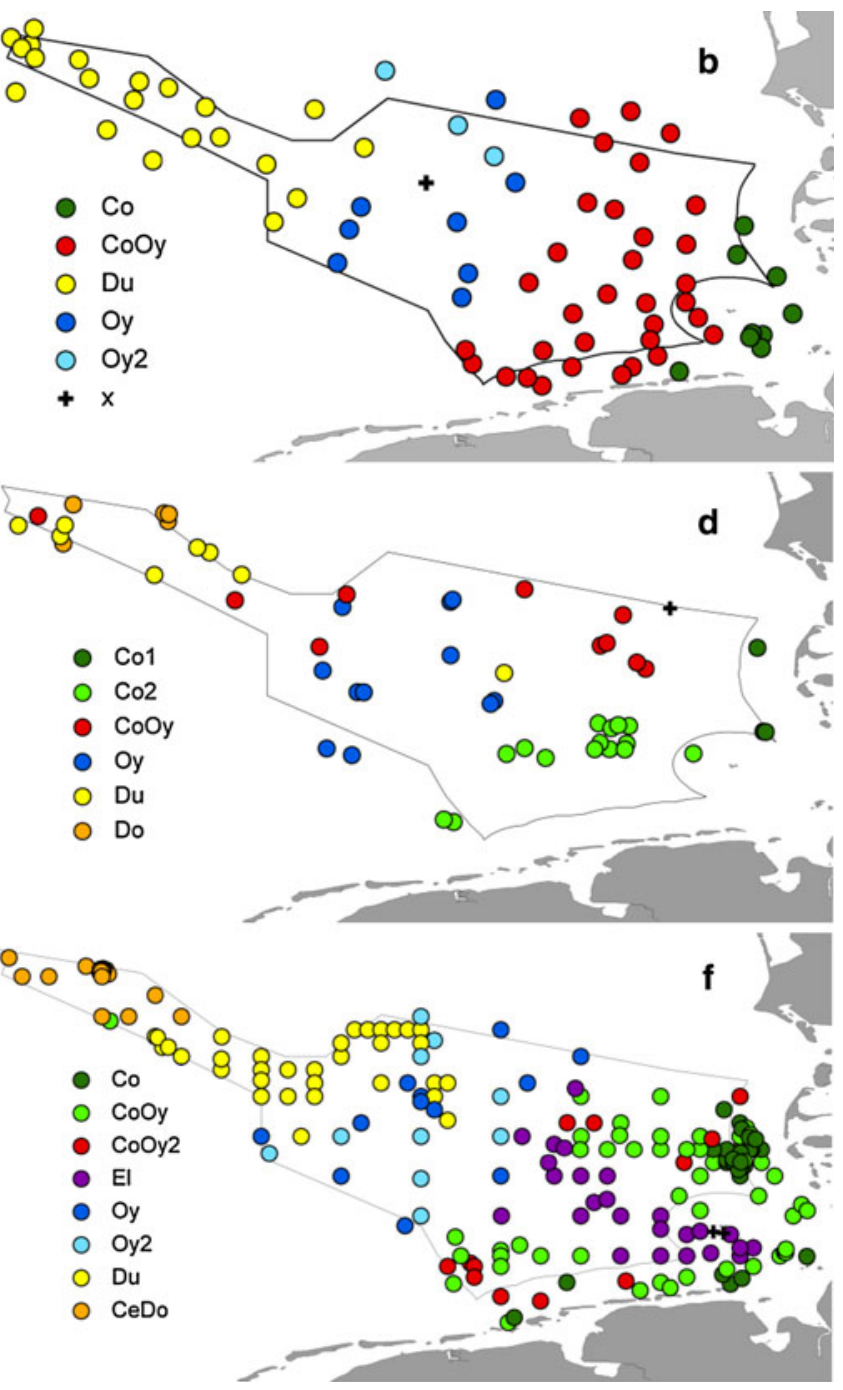

Oysterground, $\mathrm{Du}$ Duck's Bill, CoOy transitional community coast/ Oysterground, Do Dogger Bank, $E l$ post-glacial valley of the river Elbe, CeDo central North Sea/Dogger Bank)

$2+3$, ESM). High abundances and a widespread distribution in the EEZ made these species characteristic for almost all communities in the EEZ as revealed by the SIMPER analyses. However, the distribution of other species was more locally restricted. For example, the auger shell Turritella communis (Fig. 3c) or the angular crab (Fig. 3d) were predominantly found in Oysterground communities with the 2- and 7-m beam trawl, respectively. High mean abundances of the Norway lobster Nephrops norvegicus or the sea urchin Brissopsis lyrifera caught with 7-m beam trawl were responsible for the separation of the Oysterground 2 cluster (Table 1; Appendix 2, ESM). The seastar Luidia sarsi (Fig. 4c) and the whelk Buccinum undatum on the other hand were predominantly found in Duck's Bill or Dogger Bank communities.

Benthic infauna was sampled with a $0.1-\mathrm{m}^{2}$ van Veen grab on a dense station grid resulting in eight well-separated 

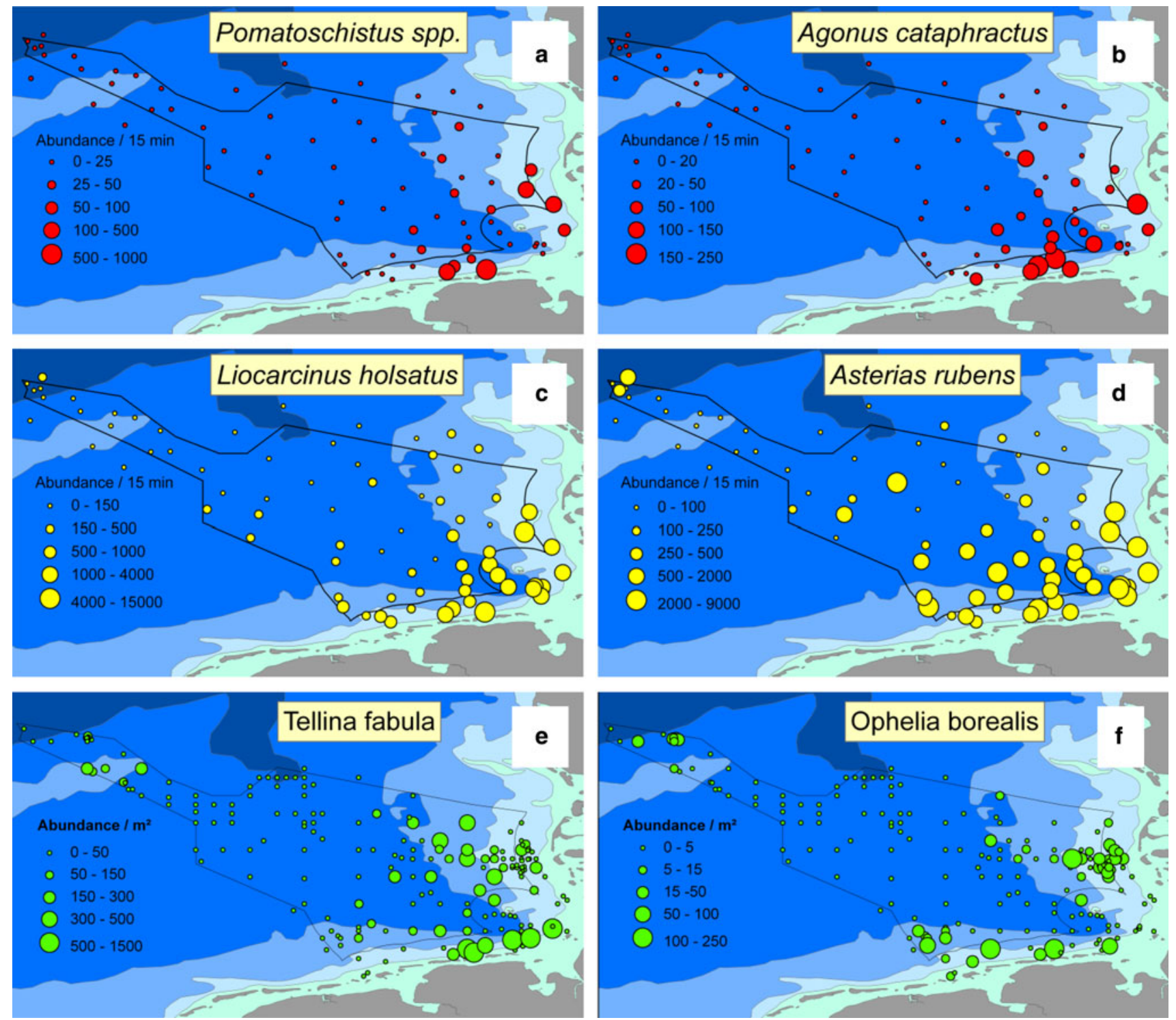

Fig. 2 Distribution and abundance of characteristic fish $(\mathbf{a}, \mathbf{b})$, epifauna $(\mathbf{c}, \mathbf{d})$ and infauna species $(\mathbf{e}, \mathbf{f})$ in coastal communities of the German EEZ. (a-d sampled with 7-m beam trawl; e and f with $0.1-\mathrm{m}^{2}$ van Veen grab)

communities (Fig. 1f). ANOSIM test shows a significant separation between communities $(R=0.70 ; p<0.001)$. Similarity within communities generally exceeded $40 \%$ (up to $52 \%$ ) with exception of the two transitional communities between coast and Oysterground ( 29 and $36 \%$ ). The coastal community was characterized, for example, by the polychaetes Ophelia borealis (Fig. 2f) and Nephtys spp., while the two transitional communities between coast and Oysterground were characterized, for example, by the bean-like tellin Tellina fabula (Fig. 2e) or the polychaetes Aonides paucibranchiata (Table 1; Appendix 4, ESM). A distinguished community in the inner German Bight was only found for benthic infauna dominated by the small bivalve $N$. nitidosa (Appendix $1+4$, ESM). Boundaries between the two Oysterground communities were not clearly defined, while distinct differences in community structure were evident. The basket shell C. gibba (Fig. 3e) was a common species in both Oysterground communities, while the polychaetes Spiophanes bombyx (Fig. 4e) and Magelona johnstoni (Appendix 4, ESM) were characterizing the Oysterground 1 community. Exceptional high abundance of the brittle star Amphiura filiformis (Fig. 3f) was characteristic for the Oysterground 2 community (Table 1), which was even higher in the Duck's Bill. High abundances of the polychaetes $S$. bombyx were found in the Duck's Bill area especially in the Central North Sea/Dogger Bank region.

Analyses revealed that identified community structure largely depends on the catchability of the gears, which is an important issue for sampling design. For example, larger 


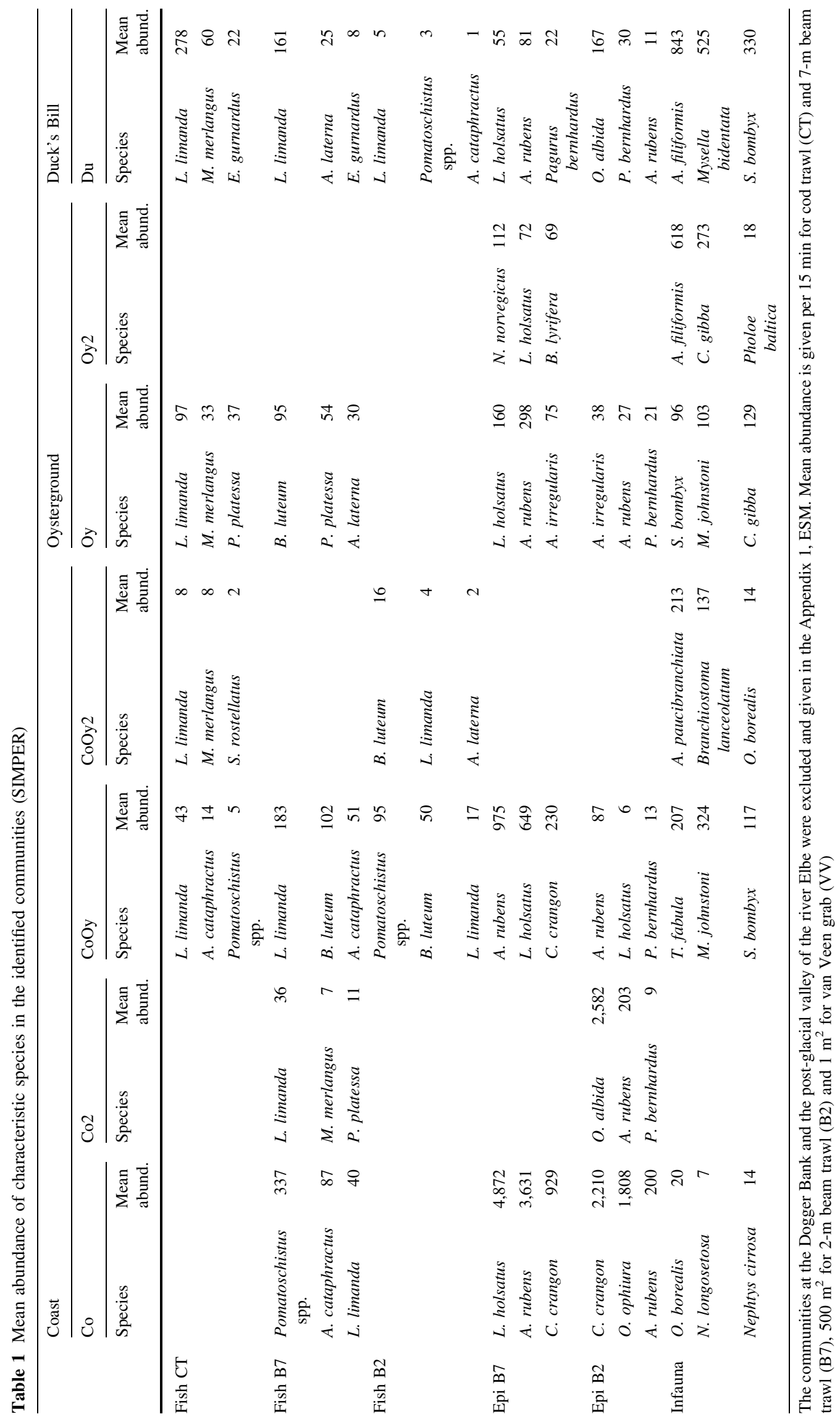



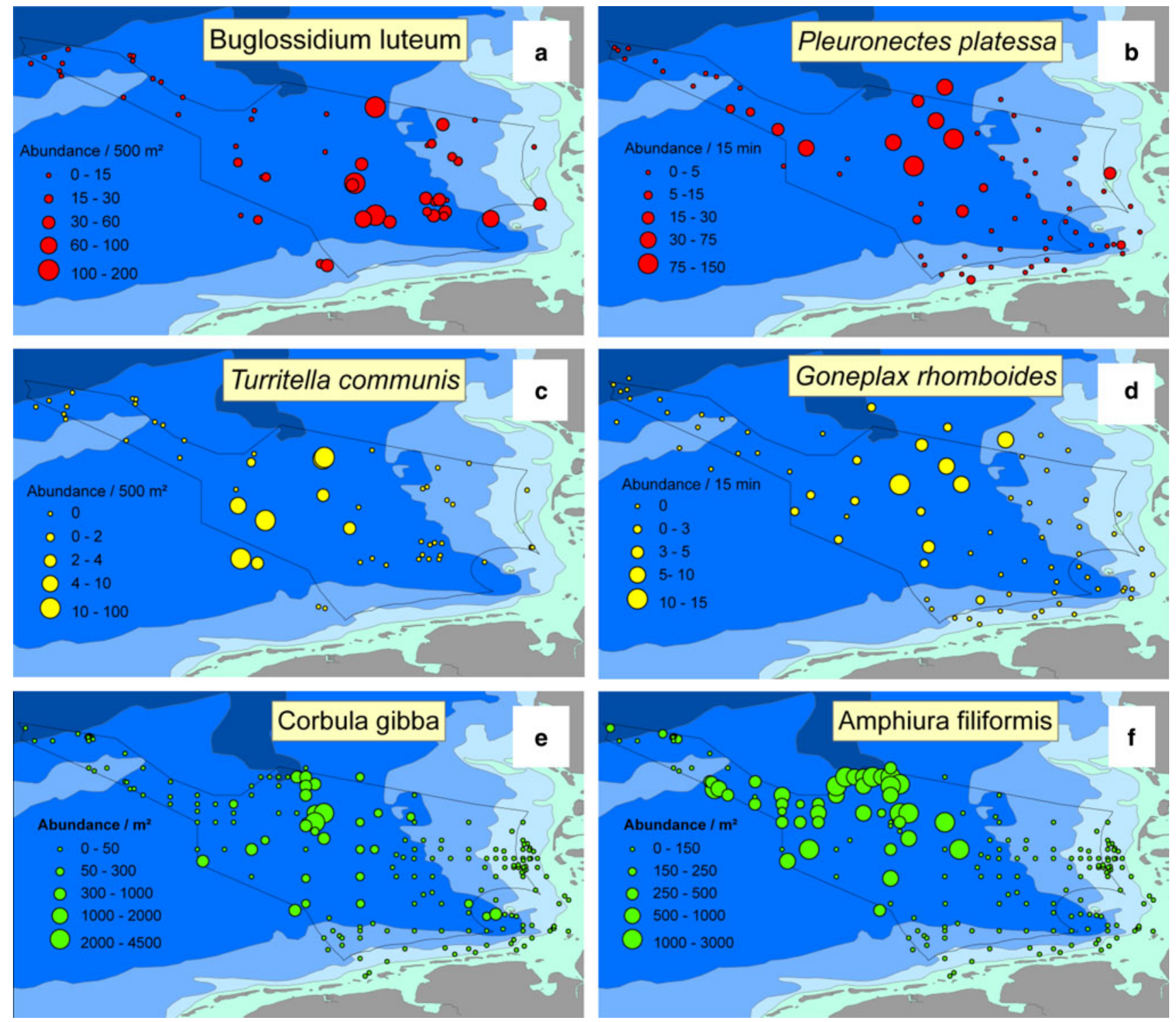

Fig. 3 Distribution and abundance of characteristic fish $(\mathbf{a}, \mathbf{b})$, epifauna $(\mathbf{c}, \mathbf{d})$ and infauna species $(\mathbf{e}, \mathbf{f})$ in Oysterground communities of the German EEZ. (a and c sampled with 2-m beam trawl; b with cod trawl; $\mathbf{d}$ with 7-m beam trawl; e and $\mathbf{f}$ with $0.1-\mathrm{m}^{2}$ van Veen grab)

fishes such as the grey gurnard E. gurnardus or the whiting M. merlangus were insufficiently sampled with the $2-\mathrm{m}$ beam trawl, while in contrast, the solenette $B$. luteum was under-represented in cod trawls. In comparison with the 2-m beam trawl, catchability of the 7-m beam trawl was higher for larger, burrowing epifauna such as the Norway lobster N. norvegicus or the angular crab Goneplax rhomboides. In contrast, catchability of the 2-m beam trawl was higher for small benthic species such as O. albida and $T$. communis. Most of these species largely influence community structure, and, for example, the epifauna community "Oysterground 2" as identified for 7-m beam trawl was not found for the 2-m beam trawl due the low catchability of this gear for species such as $N$. norvegicus.

\section{Diversity patterns}

Diversity patterns were different between faunal components, but were coinciding well between gears. Highest fish diversity (species number and $\mathrm{H}^{\prime}$ ) was generally found in southern regions of the EEZ, while contrary highest benthic diversity was found in the northern parts (Fig. 5; Table 2). However, differences in mean and total species number were low for fish and epifauna compared to benthic infauna. For example, thirteen fish species were caught in the coast/Oysterground region by using the $7-\mathrm{m}$ beam trawl, while nine species were caught in the Duck's Bill region with the same gear. In contrast, infauna species number was more than threefold lower at the coast 

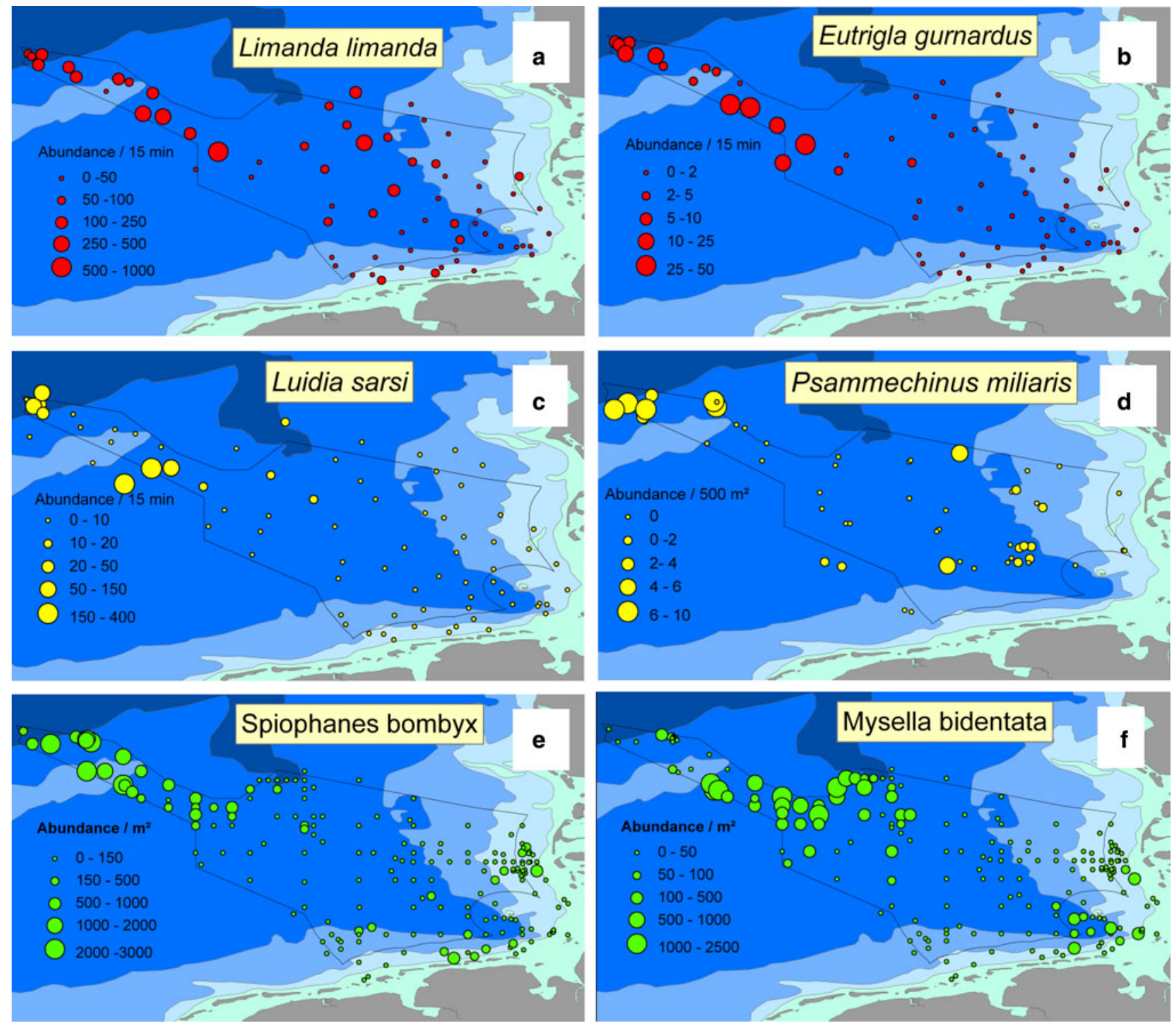

Fig. 4 Distribution and abundance of characteristic fish $(\mathbf{a}, \mathbf{b})$, epifauna $(\mathbf{c}, \mathbf{d})$ and infauna species $(\mathbf{e}, \mathbf{f})$ in Duck's Bill communities of the German EEZ. (a, b sampled with cod trawl; c with 7-m beam trawl; d with 2-m beam trawl; e, f with 0.1- $\mathrm{m}^{2}$ van Veen grab)

compared to the Central North Sea/Dogger Bank region (Fig. 5; Table 2).

Comparisons of community structures and habitat classification

The RELATE analyses were used to test the similarities between community patterns and to identify interrelationships between them. It was found that the spatial community structures of all faunal components were in most cases significantly correlated (Table 3). Exceptions were the community patterns of fish caught with the cod trawl and the 2-m beam trawl, as well as fish (CT) and epifauna (B2), which is largely due to the low spatial fit of stations in these datasets. Highest correlations were found between epifauna and fish caught with the 7-m beam trawl ( $\rho=0.67 ; p<0.001)$ as well as epifauna (B7) and fish (B2) $(\rho=0.55 ; p<0.001)$. Correlations between benthic infauna patterns and the other faunal components were generally low, which might be due to the very high sampling resolution of the benthic infauna dataset. However, despite of the different sampling resolution of datasets, it became obvious that number of identified communities generally increased from fish to benthic infauna (at the same level of similarity within clusters) which corresponds to an increasing species number from fish to benthic infauna (Fig. 5). Additionally, the importance of smallscale sediment characteristics as well as mobility decreases from fish to benthic infauna which also influences community structure largely (see discussion). 

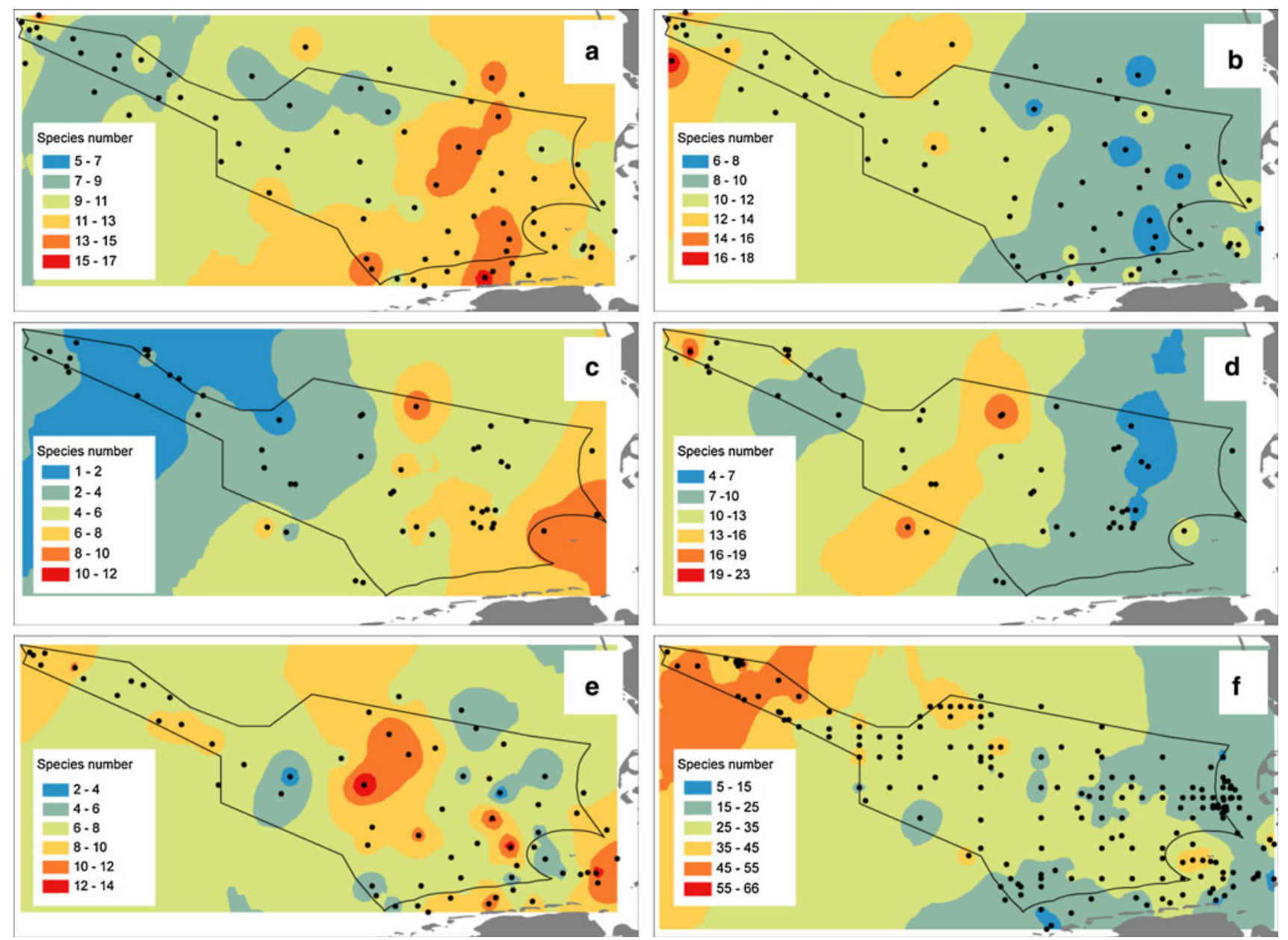

Fig. 5 Interpolated species number (inverse distance weighting) per sample/haul of fish (a, c, e), epifauna (b, d) and infauna (f) sampled with 7-m beam trawl $(\mathbf{a}, \mathbf{b}), 2-\mathrm{m}$ beam trawl $(\mathbf{c}, \mathbf{d})$, cod trawl $(\mathbf{e})$ and $0.1-\mathrm{m}^{2}$ van Veen grab (f)

Although small-scale differences in community structure were found especially for benthic infauna, a general separation into a coastal, an Oysterground and a Duck's Bill community was evident for all three faunal components (Fig. 1; roughly sketched in Fig. 6), which is largely based on the distribution and abundance of characteristic species. Dominant species in these communities were, for example, the goby Pomatoschistus spp., the grey gurnard E. gurnardus, the swimming crab L. holsatus, the seastar $A$. rubens or the polychaetes $S$. bombyx and $O$. borealis (Figs. 2, 3, 4). The spatial patterns of community structure largely correspond to abiotic habitat characteristics as reviewed in Table 4 and shown in Fig. 6. Especially bottom temperature variation between summer and late autumn/winter largely differed between the coast, the Oysterground and the Duck's Bill with highest variation at the coast $\left(12{ }^{\circ} \mathrm{C}\right)$ and lowest variation in the Duck's Bill $\left(3-4{ }^{\circ} \mathrm{C}\right.$ ) from 1998 to 2008 . Lowest late autumn/winter bottom temperatures $\left(1.98{ }^{\circ} \mathrm{C}\right)$ and highest summer bottom temperatures $\left(18.48^{\circ} \mathrm{C}\right)$ were recorded at the coast in 2003 and 1999, respectively. In general, the regions follow an increasing gradient of bottom temperature in late autumn/ winter and a decreasing one in summer, from the coast to the Duck's Bill (Fig. 6; Table 4). Salinity, length of thermal stratification and strength of residual currents also increased from the coast to the Duck's Bill, while tidal stress, sedimentation rate and sediments parameter such as total organic carbon and chlorophyll $a$ decreased with distance from shore (Table 4).

\section{Discussion}

This study revealed a general separation of fish, epifauna and infauna communities in the German EEZ into a coast, an Oysterground and a Duck's Bill community, which coincided well with large-scale abiotic characteristics of the German EEZ. Gradients of temperature, salinity, stratification, tidal stress as well as total organic carbon (TOC) and chlorophyll $a$ were found in the German EEZ, 
Table 2 Mean diversity and abundance of fish, epifauna and infauna within the habitats identified with cluster analysis and MDS

\begin{tabular}{|c|c|c|c|c|c|c|c|c|c|c|}
\hline & \multicolumn{5}{|l|}{ Coast } & \multicolumn{2}{|c|}{ Oysterground } & \multicolumn{3}{|c|}{ Duck’s Bill } \\
\hline & $\mathrm{Co}$ & $\mathrm{Co} 2$ & $\mathrm{CoOy}$ & $\mathrm{CoOy} 2$ & El & Oy & Oy2 & $\mathrm{Du}$ & Do & CeDo \\
\hline \multicolumn{11}{|c|}{ Fish $C T$} \\
\hline $\mathrm{H}^{\prime}$ & & & 1.8 & 1.7 & & 1.6 & & 1.4 & 0.9 & \\
\hline sp. nr. & & & 10 & 6 & & 9 & & 8 & 6 & \\
\hline abun. & & & 78 & 22 & & 182 & & 407 & 107 & \\
\hline \multicolumn{11}{|c|}{ Fish B7 } \\
\hline $\mathrm{H}^{\prime}$ & 2.0 & 2.5 & 2.3 & & & 2.2 & & 1.7 & & \\
\hline sp. nr. & 12 & 11 & 13 & & & 10 & & 9 & & \\
\hline abun. & 541 & 119 & 459 & & & 224 & & 236 & & \\
\hline \multicolumn{11}{|c|}{ Fish B2 } \\
\hline $\mathrm{H}^{\prime}$ & & & 1.7 & 1.4 & & & & 1.0 & & \\
\hline sp. nr. & & & 6 & 4 & & & & 3 & & \\
\hline abun. & & & 191 & 26 & & & & 10 & & \\
\hline \multicolumn{11}{|l|}{ Epi B7 } \\
\hline $\mathrm{H}^{\prime}$ & 1.9 & & 1.8 & & & 2.0 & 1.6 & 2.5 & & \\
\hline sp. nr. & 10 & & 9 & & & 11 & 10 & 12 & & \\
\hline abun. & 12,126 & & 2,185 & & & 596 & 296 & 331 & & \\
\hline \multicolumn{11}{|l|}{ Epi B2 } \\
\hline $\mathrm{H}^{\prime}$ & 1.7 & 1.0 & 1.8 & & & 2.2 & & 1.8 & 1.7 & \\
\hline sp. nr. & 8 & 8 & 10 & & & 15 & & 9 & 12 & \\
\hline abun. & 4,407 & 2,929 & 158 & & & 565 & & 254 & 257 & \\
\hline \multicolumn{11}{|c|}{ Infauna $V V$} \\
\hline $\mathrm{H}^{\prime}$ & 2.9 & & 2.9 & 3.0 & 3.5 & 3.7 & 2.6 & 3.0 & & 2.9 \\
\hline sp. nr. & 14 & & 27 & 18 & 31 & 28 & 24 & 35 & & 46 \\
\hline abun. & 230 & & 1,865 & 1,046 & 1,933 & 874 & 1,262 & 2,992 & & 2,781 \\
\hline
\end{tabular}

$H^{\prime}$ mean Shannon-Wiener index; sp. $n r$. mean species number; abun. mean abundance per region; highest values indicated in bold

Table 3 Correlation coefficients (Rho) relating the similarity matrices of the different communities (RELATE)

\begin{tabular}{llllll}
\hline & Fish B2 & Fish CT & Fish B7 & Epi B2 & Endo \\
\hline Epi B7 & $0.55^{*}$ & $0.33^{*}$ & $0.67^{*}$ & $0.30^{*}$ & $0.46^{*}$ \\
Endo & $0.31^{*}$ & $0.25^{*}$ & $0.27^{*}$ & $0.44^{*}$ & \\
Epi B2 & $0.22^{*}$ & 0.24 & $0.35^{*}$ & & \\
Fish B7 & $0.52^{*}$ & $0.50^{*}$ & & & \\
Fish CT & 0.29 & & & & \\
\hline
\end{tabular}

Significance level $p<0.001$ is indicated by *

which correspond to these three communities and seem to have a higher influence on community structure than, for example, biotic interactions on that spatial scale. Thus, we conclude that the coast, the Oysterground and the Duck's Bill were common habitats, which were distinguishable by their abiotic characteristics and associated biological communities (Fig. 2).

The coastal habitat is characterized by water masses, which are largely influenced by fresh water run-off from rivers resulting in low salinity and high nutrient input
(Continental Coastal Water; according to Laevastu 1963). Additionally, water in the coastal habitat is well mixed throughout the year beneath the 20-30-m depth contour (Becker et al. 1992) resulting in high seasonal temperature variations (Fig. 6). As a consequence, species in coastal habitats were more strongly affected by extreme climatic events such as cold winters, but were also better adapted to strong seasonal temperature variations (Reiss et al. 2006b; Neumann et al. 2009). Species commonly found in the coastal habitat such as gobies, the pipefish Syngnathus rostellatus or the brittle star $O$. albida are known to have a high tolerance towards temperature and salinity variation (Ursin 1960; Knijn et al. 1993). High nutrient input, together with a relatively long residence time of the water masses in the coastal habitat, could also result in intense algal blooms and, therefore, in increased food supply for benthic fauna (Dauwe et al. 1998; Stöck and Kröncke 2001). Generally, most abiotic habitat characteristics changed gradually from the coast towards the Duck's Bill area (Table 4). For example, length of summer stratification increased towards the Duck's Bill, where a stable 

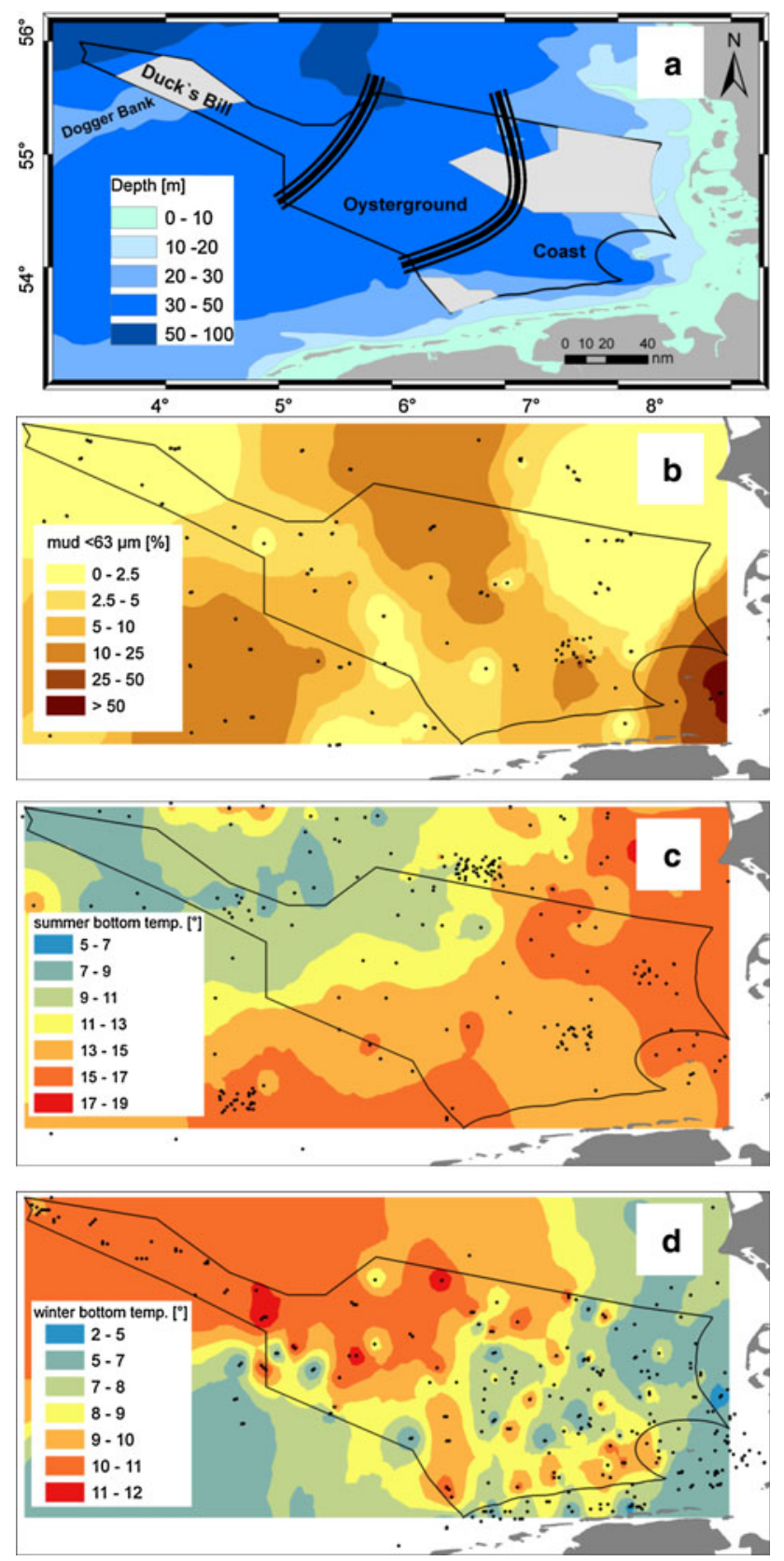

Fig. 6 Location and depth of the German (EEZ) in the North Sea (bold lines are suggested habitat boundaries; grey areas are Natura 2000 sites) (a). Percentage mud ( $<63 \mu \mathrm{m}$ sieve fraction) of sediments in the German EEZ (b). Summer (c) and late autumn/winter (d) bottom temperature in the German EEZ (b-d were interpolated by using "inverse distance weighting")

thermal stratification occurs from May to September. Water masses (central North Sea water) in the Duck's Bill habitat were characterized by lower seasonal temperature variation as well as medium salinity and nutrient concentration (Laevastu 1963; Becker et al. 1992). Furthermore, stratification processes inhibited sedimentation of organic matter to the bottom and vice versa input of nutrients from bottom waters into upper layers, which resulted in a decreasing trend of TOC and chlorophyll $a$ (Table 4), and hence food supply especially for benthic infauna species, from the coast to the Duck's Bill (Kröncke et al. 2004). Most abiotic habitat characteristics and especially temperature (Fig. 6) exhibit strong seasonal variability, which largely differ between the habitats. Thus, it is assumed that the differences in the seasonal variability with respect to many abiotic habitat characteristics are the most important factor discriminating the habitats coast, Oysterground and Duck's Bill.

The three habitats coast, Oysterground and Duck's Bill are the major habitats common for demersal fish, epifauna and infauna in the German EEZ. However, it should be noted that these habitats were rather confined by gradual transitions than by conspicuous boundaries, which is supported by transitional communities found in this study. Additionally, small-scale habitats were obvious for single faunal components (or even species) since the importance of habitat characteristics depends on the spatial scale (Menge and Olson 1990) and on the faunal component (or species) under consideration (e.g. due to different mobility). Spatial variability of benthic infauna, for example, was often linked to sediment characteristics, which were related to food supply (Künitzer et al. 1992; Kröncke 2006). Sediments in the German EEZ are heterogeneous distributed consisting mainly of terrigenous sand, mud or a mixture of both ("Sublittoral sand" and "Sublittoral mud" after EUNIS classification 5.2 and 5.3). Locally, areas of morainic origin such as the "Borkum Riffgrund" or the "Helgoländer Steingrund" occur in the German EEZ, where also pebbles and boulders were found (EUNIS 5.1 "Sublittoral coarse sediment" and 4.7 "circalittoral rock"). This small-scale habitat heterogeneity within our three habitats provided also the basis of the selection of the Natura 2000 sites "Borkum Reef Ground", "Dogger Bank" and "Sylter Outer Reef" in the North Sea (Fig. 6), where a total of $2,322 \mathrm{~km}^{2}$ of the habitat type "sandbanks" and $176 \mathrm{~km}^{2}$ of the habitat type "reefs" were located (Pedersen et al. 2009). Small-scale habitat heterogeneity resulted in particular community structures in this study, for example, the Dogger Bank, where the largest area of "sandbanks" in the EEZ is located (Fig. 1; Appendix 1, ESM) or the inner German Bight, where high abundances of the benthic infauna species $N$. nitidosa were found, which is a typical indicator for muddy sediments (Rachor 1980). Mud content of sediment also influenced the distribution of the Norway lobster $N$. norvegicus and the angular crab G. rhomboides (unpublished data), which both were tube-building species characteristic for specific areas in the Oysterground habitat. Additionally, the basket shell $C$. gibba, which revealed a similar distribution as the Norway lobster in the Oysterground, were often related to muddy, organically enriched sediments (Holmes and Miller 
Table 4 Habitat characteristics at the coast, the Oysterground and the Duck's Bill

\begin{tabular}{|c|c|c|c|c|}
\hline & Coast & Oysterground & Duck's Bill & \\
\hline TOC (sediment) & High & Moderate & Low & $\begin{array}{l}\text { Kröncke et al. (2004), Reiss and Kröncke (2005), } \\
\text { Stöck and Kröncke (2001) }\end{array}$ \\
\hline Chl $a$ (sediment) & High & Moderate & Moderate to high & $\begin{array}{l}\text { Kröncke et al. (2004), Reiss and Kröncke (2005), } \\
\text { Boon and Duineveld (1998), Stöck et al. (2002) }\end{array}$ \\
\hline Mud content & High & Low to moderate & Low & $\begin{array}{l}\text { Kröncke et al. (2004), Reiss and Kröncke (2005), } \\
\text { Stöck et al. (2002) }\end{array}$ \\
\hline Sedimentation rate & High & Moderate & Low & Kröncke et al. (2004), Stöck et al. (2002) \\
\hline Tidal stress & High & Moderate & Low & Becker et al. (1992), Dippner (1993) \\
\hline Summer bottom temperature & High & Moderate & Low & Neumann et al. (2009), Ehrich et al. (2007) \\
\hline Winter bottom temperature & Low & Moderate & High & Neumann et al. (2009), Ehrich et al. (2007) \\
\hline Salinity & Low & Moderate & High & Becker et al. (1992), Ehrich et al. (2007) \\
\hline Length of thermal stratification & Low & Moderate & High & Neumann et al. (2009), Becker et al. (1992); \\
\hline Residual currents & Low & Moderate to high & Moderate to high & Becker et al. (1992) \\
\hline
\end{tabular}

2006). However, with exception of the infauna dataset, the sampling resolution of this study was too coarse to analyse community structure of small-scale habitat types such as "reefs". On the other hand, the importance of small-scale habitat types for the geographical limits of communities is decreasing with increasing mobility of species (generally increasing from benthic infauna to fish).

\section{Habitat stability}

A central question, for example, for management approaches is whether habitats are stable over time.

Kröncke et al. (2011) found no fundamental shifts for benthic infauna communities in the last decades on North Sea wide scale even if single species such as $N$. nitidosa slightly shifted their core distribution. This seems to be true also for the German EEZ, because Rachor and Nehmer (2003) found similar patterns to those described by Salzwedel et al. (1985) in the 1980s and Hagmeier (1925) in 1920 s, indicating that no considerable and permanent changes of infauna community structure occurred over a period of almost 80 years. This might be partly explained by the comparatively stable sediment distribution in the EEZ, which is a more important habitat characteristic for benthic infauna than for other faunal components (Callaway et al. 2002; Schratzberger et al. 2006). Otherwise, it is reasonable that the general community structure of fish, epifauna and infauna characterizing the habitats coast, Oysterground and Ducks Bill remained rather stable over time since abiotic habitat characteristics such as different strength in seasonality of, for example, temperature have a larger influence on the general community structure than, for example, gradual warming of the water column due to climate change. However, contrary to communities distribution of single species was not stable but dynamic on seasonal and annual timescales. Many species revealed seasonal migration to avoid unfavourable temperatures in winter, while the spatial extend of this migration largely depends on the mobility of species (decreasing from fish to benthic infauna). For example, abundance of the grey gurnard E. gurnardus changed considerably between seasons with high abundances in the western part of the central North Sea in winter and high densities in the southern Bight in summer (Knijn et al. 1993). Seasonal migration between spawning and feeding grounds is also well known for the plaice Pleuronectes platessa (Knijn et al. 1993; van Keeken et al. 2007) and might partly explain the different distribution patterns of the plaice found in this study. Shrimps such as $C$. crangon are known to migrate seasonally between shallow coastal water (summer) and deeper offshore water (winter) to avoid unfavourable winter conditions (Boddeke 1976; Temming and Damm 2002). Not only temperature, but also other abiotic habitat characteristics were changing seasonally such as onshore wave stress, which increases in winter and is suggested to trigger the seasonal migration of the seastar Astropecten irregularis into deeper water (Freeman et al. 2001).

Habitat characteristics are changing also on long-term temporal scales. Beare et al. (2002) found an increase in late winter temperature (January, February) of ca. $1.1^{\circ} \mathrm{C}$ in the German Bight between the early 1950s and the late 1990s. Additionally, salinity rose and stratification intensity decreased east of ca. $5^{\circ} \mathrm{E}$. Increasing temperature in the German Bight resulted in small-scale distribution shifts of demersal fish species such as $P$. platessa, B. luteum and Arnoglossus laterna (van Keeken et al. 2007; van Hal et al. 2010), which dominated several communities found in this study. As a consequence, management tools such as the "Plaice Box" (a coastal area closed for fishing to protect young plaice) lose effectiveness since juvenile plaice shifted its distribution towards more offshore waters (van Keeken et al. 2007). Ehrich et al. (2007) found that 
demersal fish communities in the German Bight shifted from a gadoid-dominated community to a flatfish-dominated community in a period from 1987 to 2005. Distribution shifts in a sense of natural range expansion of, for example, southern species into the German EEZ were also found in the last decades. Recently, the angular crab G. rhomboides extended its distribution from the eastern Atlantic to the southern North Sea (Neumann et al. 2010) and also southern fish species such as the tub gurnard Trigla lucerna, the red mullet Mullus surmuletus and the pilchard Sardina pilchardus were now regularly found in the German Bight (Ehrich and Stransky 2001; Beare et al. 2004; Ehrich et al. 2007). In contrast, Kröncke et al. (2011) found no indications for range expansions of non-native benthic infauna species by a comparison of infauna communities between 1986 and 2000 on a North Sea wide scale. So far, these climate-related effects influenced only single species rather than communities as a whole. Additionally, climate change effects were rather expressed as changes in abundance of species in the EEZ habitats, which were, for example, related to temperature-mediated increase in primary production and, thus, food supply for benthos (Kröncke et al. 1998; Neumann et al. 2009; Kröncke et al. 2011). However, the coastal habitat was more sensitive to climate-related temperature changes compared to the more stable and stratified habitats Oysterground and Duck's Bill. On the one hand, the effects of extreme climatic events such as cold winters were more pronounced in the well-mixed coastal habitat than in more stable offshore habitats (Reiss et al. 2006b; Neumann et al. 2009). Cold winters influence benthic fauna through enhanced mortality and reduced reproduction and production. These effects were observed as a reduced number of species as well as decreased diversity, biomass and secondary production (Ziegelmeier 1970; Buchanan and Moore 1986; Beukema 1992; Kröncke et al. 1998). Additionally, mass occurrences of r-selective species such as epibenthic brittle star $O$. albida were related to cold winter temperatures (Neumann et al. 2009). The effects of such extreme events influenced habitats for several years, and recovery time of communities in disturbed habitats was found to be 2-5 years for benthic infauna and 7-8 years for benthic epifauna (Schröder 2003; Neumann and Kröncke 2011). On the other hand, cold winters only rarely occurred in the last decade and increasing sea surface temperature has more direct effects on bottom living species in the coastal habitat due to the mixed water column. Consequently, it can be assumed that the coastal habitat will be more affected by climate change effects in future compared to the Oysterground and Duck's Bill habitat.

Acknowledgments We thank the captains and crews of RV "Walther Herwig III" and "Solea" for their assistance during sampling. The present study was conducted at the Biodiversity and Climate Research Centre (BiK-F), Frankfurt a.M. and financially supported by the research funding programme "LOEWE -LandesOffensive zur Entwicklung Wissenschaftlich-ökonomischer Exzellenz" of Hesse's Ministry of Higher Education, Research and the Arts.

\section{References}

Beare DJ, Batten S, Edwards M, Reid DG (2002) Prevalence of boreal Atlantic, temperate Atlantic and neritic zooplankton in the North Sea between 1958 and 1998 in relation to temperature, salinity, stratification intensity and Atlantic inflow. J Sea Res 48:29-49

Beare DJ, Burns F, Greig A, Jones EG, Peach K, Kienzle M, McKenzie E, Reid DG (2004) Long-term increases in prevalence of North Sea fishes having southern biogeographic affinities. Mar Ecol Prog Ser 284:269-278

Becker G, Dick S, Dippner JW (1992) Hydrography of the German Bight. Mar Ecol Prog Ser 91:9-18

Beukema JJ (1992) Expected changes in the Wadden Sea benthos in a warmer world: lessons from periods with mild winters. Neth J Sea Res 30:73-79

BMU (2012) Umsetzung der Meeresstrategie-Rahmenrichtlinie: Anfangsbewertung der deutschen Nordsee. Bundesministerium für Umwelt, Naturschutz und Reaktorsicherheit, Bonn

Boddeke R (1976) The seasonal migration of the brown shrimp Crangon crangon. Neth J Sea Res 10(1):103-130

Boon AR, Duineveld GCA (1998) Chl a as a marker for bioturbation and carbon flux in southern and central North Sea sediments. Mar Ecol Prog Ser 162:33-43

Buchanan JB, Moore DC (1986) Long-term studies at a benthic station off the coast of Northumberland. Hydrobiol 142:121-127

Callaway R, Alsvag J, de Boois I, Cotter J, Ford A, Hinz H, Jennings S, Kröncke I, Lancaster J, Piet G, Prince P, Ehrich S (2002) Diversity and community structure of epibenthic invertebrates and fish in the North Sea. ICES J Mar Sci 59:1199-1214

Commission E (1992) Council Directive 92/43/EEC of 21 May 1992 on the conservation of natural habitats and of wild fauna and flora. Off J Eur Union L206:7-50

Commission E (2008) Directive 2008/56/EC of the European Parliament and of the Council of 17 June 2008, establishing a framework for community action in the field of marine environmental policy (Marine Strategy Framework Directive). Off J Eur Union L164:19-40

Daan N, Bromley PJ, Hislop JRG, Nielsen NA (1990) Ecology of North Sea fish. Neth J Sea Res 26(2-4):343-386

Dauwe B, Herman PMJ, Heip C (1998) Community structure and bioturbation potential of macrofauna at four North Sea stations with contrasting food supply. Mar Ecol Prog Ser 173:67-83

Dippner JW (1993) A frontal-resolving model for the German Bight. Cont Shelf Res 13:49-66

Duineveld GCA, Künitzer A, Niermann U, De Wilde PAWJ, Gray JS (1991) The macrobenthos of the North Sea. Neth J Sea Res 28(1/2):53-65

Dyer MF, Fry WG, Fry PD, Cranmer GJ (1982) A series of North Sea benthos surveys with trawl and headline camera. J mar biol Ass UK 62:297-313

Dyer MF, Fry WG, Fry PD, Cranmer GJ (1983) Benthic regions within the North Sea. J mar biol Ass UK 63:683-693

Ehrich S, Stransky C (2001) Spatial and temporal changes in the southern species component of North Sea fish assemblages. Senckenb Marit 31(2):143-150

Ehrich S, Adlerstein S, Brockmann U, Floeter J, Garthe S, Hinz H, Kröncke I, Neumann H, Reiss H, Sell AF, Stein M, 
Stelzenmüller V, Stransky C, Temming A, Wegner G, Zauke GP (2007) 20 years of the German Small-Scale Bottom Trawl Survey (GSBTS): a review. Senckenb Marit 37:13-82

Ehrich S, Stelzenmuller V, Adlerstein S (2009) Linking spatial pattern of bottom fish assemblages with water masses in the North Sea. Fish Oceanogr 18(1):36-50

Frauenheim K, Neumann V, Thiel H, Türkay M (1989) The distribution of the larger epifauna during summer and winter in the North Sea and its suitability for environmental monitoring. Senckenb Marit 20(3/4):101-118

Freeman SM, Richardson CA, Seed R (2001) Seasonal abundance, spatial distribution, spawning and growth of Astropecten irregularis (Echinodermata: Asteroidea). Est Coast Shelf Sci 53:39-49

Greenstreet SPR, Hall SJ (1996) Fishing and the ground-fish assemblage structure in the north-western North Sea: an analysis of long-term and spatial trends. J Anim Ecol 65(5):577-598

Hagmeier A (1925) Vorläufiger Bericht über die vorbereitenden Untersuchungen der Bodenfauna der Deutschen Bucht mit dem Petersen-Bodengreifer. Ber dt wiss Komm Meeresforsch B. NF 1:247-272

Heip C, Basford DJ, Craeymeersch JA, Dewarumez JM, Dörjes J, De Wilde PAWJ, Duineveld G, Eleftheriou A, Herman PMJ, Niermann U, Kingston P, Künitzer A, Rachor E, Rumohr H, Soetaert K, Soltwedel T (1992) trends in biomass, density and diversity of North Sea macrofauna. ICES J Mar Sci 49:12-22

Holmes SP, Miller N (2006) Aspects of the ecology and population genetics of the bivalve Corbula gibba. Mar Ecol Prog Ser 315:129-140. doi:10.3354/meps315129

ICES (2006) Report of the Working Group on Marine Habitat Mapping (WGMGM). ICES CM 2006/MHC:05, Galway, Ireland

Jennings S, Lancaster J, Woolmer A, Cotter J (1999) Distribution, diversity and abundance of epibenthic fauna in the North Sea. J mar biol Ass UK 79:385-399

Kearney M (2006) Habitat, environment and niche: what are we modelling? Oikos 115(1):186-191

Knijn RJ, Boon TW, Heessen HJL, Hislop JRG (1993) Atlas of North Sea fishes. ICES cooperative research report. International Council for the Exploration of the Sea, Copenhagen

Kröncke I (2006) Structure and function of macrofaunal communities influenced by hydrodynamically controlled food availibility in the Wadden Sea, the open North Sea, and the Deep Sea. A synopsis. Senckenb Marit 36:123-164

Kröncke I, Dippner JW, Heyen H, Zeiss B (1998) Long-term changes in macrofaunal communities off Norderney (East Frisia, Germany) in relation to climate variability. Mar Ecol Prog Ser 167:25-36

Kröncke I, Reiss H, Eggleton JD, Aldridge J, Bergmann MJN, Cochrane S, Craeymeersch JA, Degraer S, Desroy N, Dewarumez JM, Duineveld GCA, Essink K, Hillewaert H, Lavaleye MSS, Moll A, Nehring S, Newell R, Oug E, Pohlmann T, Rachor E, Robertson M, Rumohr H, Schratzberger M, Smith R, Vanden Berghe E, van Dalfsen J, van Hoey G, Vincx M, Wouter W, Rees HL (2011) Changes in North Sea macrofauna communities and species distribution between 1986 and 2000. Est Coast Shelf Sci 94(1):1-15

Kröncke I, Stöck T, Wieking G, Palojärvi A (2004) Relationship between structural and trophic aspects of microbial and macrofaunal communities in different areas of the North Sea. Mar Ecol Prog Ser 282:13-31

Künitzer A, Basford D, Craeymeersch JA, Dewarumez JM, Dörjes J, Duineveld GCA, Eeleftheriou A, Heip C, Herman P, Kingston P, Niermann U, Rachor E, Rumohr H, de Wilde PAJ (1992) The benthic infauna of the North Sea: species distribution and assemblages. ICES J Mar Sci 49:127-143

Laevastu T (1963) Serial atlas of the marine environment: surface water types of the North Sea and their characteristics, vol 4. American Geography Society, New York
Menge BA, Olson AM (1990) Role of scale and environmental factors in regulation of community structure. Trends Ecol Evol $5(2): 52-57$

Neumann H, Kröncke I (2011) The effect of temperature variability on ecological functioning of epifauna in the German Bight. PSZN I: Mar Ecol 32(Suppl. 1):1-9

Neumann H, Reiss H, Rakers S, Ehrich S, Kröncke I (2009) Temporal variability of southern North Sea epifauna communities after the cold winter 1995/1996. ICES J Mar Sci 66:2233-2243

Neumann H, Kröncke I, Ehrich S (2010) Establishment of the angular crab Goneplax rhomboides (Linnaeus, 1758) (Crustacea, Decapoda, Brachyura) in the southern North Sea. Aquat Invasions 5(Suppl 1):S27-S30

Pedersen SA, Fock H, Krause J, Pusch C, Sell AL, Boettcher U, Rogers SI, Skold M, Skov H, Podolska M, Piet GJ, Rice JC (2009) Natura 2000 sites and fisheries in German offshore waters. ICES J Mar Sci 66(1):155-169. doi:10.1093/icesjms/ fsn193

Petersen CGJ (1914) Valuation of the sea. II. The animal communities of the sea bottom and their importance for marine zoogeography. Report of the Danish Biological Station 21:1-44

Rachor E (1980) The inner German Bight—an ecologically sensitive area as indicated by the bottom fauna. Helgoländer Meeresunters 33:522-530

Rachor E, Nehmer P (2003) Erfassung und Bewertung ökologisch wertvoller Lebensräume in der Nordsee. Abschlussbericht für das F + E Vorhaben FKZ 89985 310. Bundesamt für Naturschutz, Bonn

Rees HL, Eggleton JD, Rachor E, Vanden Berghe E (2007) Structure and dynamics of the North Sea benthos. ICES Cooperative Research Report 288. ICES, Copenhagen

Reiss H, Kröncke I (2005) Seasonal variability of infaunal community structures in three areas of the North Sea under different environmental conditions. Est Coast Shelf Sci 65:253-274

Reiss H, Kröncke I, Ehrich S (2006a) Estimating catch efficiency of a $2 \mathrm{~m}$ beam trawl for sampling epifauna by removal experiments. ICES J Mar Sci 63:1453-1464

Reiss H, Meybohm K, Kröncke I (2006b) Cold winter effects on benthic macrofauna communities in near- and offshore regions of the North Sea. Helgoland Mar Res 60:224-238

Reiss H, Degraer S, Duineveld GCA, Kroncke I, Aldridge J, Craeymeersch JA, Eggleton JD, Hillewaert H, Lavaleye MSS, Moll A, Pohlmann T, Rachor E, Robertson M, Vanden Berghe E, van Hoey G, Rees HL (2010) Spatial patterns of infauna, epifauna, and demersal fish communities in the North Sea. ICES J Mar Sci 67(2):278-293. doi:10.1093/icesjms/fsp253

Salzwedel H, Rachor E, Gerdes D (1985) Benthic macrofauna communities in the German Bight. Verff Inst Meeresforsch Bremerhav 20:199-267

Schratzberger M, Warr K, Rogers SI (2006) Patterns of nematode populations in the southwestern North Sea and their link to other components of the benthic fauna. J Sea Res 55(2):113-127. doi: 10.1016/j.seares.2005.07.002

Schröder A (2003) Community dynamics and development of soft bottom benthos in the German Bight (North Sea) 1969-2000. $\mathrm{PhD}$, University Bremen (Germany), Bremen

Stöck T, Kröncke I (2001) Influence of particle mixing on vertical profiles of chlorophyll $a$ and bacterial biomass in sediments of the German Bight, Oyster Ground and Dogger Bank (North Sea). Est Coast Shelf Sci 52:783-795

Stöck T, Kröncke I, Duineveld GCA, Palojärvi A (2002) Phospholipid fatty acid profiles at depositional and non-depositional sites in the North Sea. Mar Ecol Prog Ser 241:57-70

Temming A, Damm U (2002) Life cycle of Crangon crangon in the North Sea: a simulation of the timing of recruitment as a function of the seasonal temperature signal. Fish Oceanogr 11:45-58 
Ursin E (1960) A quantitative investigation of the echinoderm fauna of the central North Sea. Medd Dan Fisk Havunders 2:1-204

van Hal R, Smits K, Rijnsdorp AD (2010) How climate warming impacts the distribution and abundance of two small flatfish species in the North Sea. J Sea Res 64(1-2):76-84. doi: 10.1016/j.seares.2009.10.008

van Keeken OA, van Hoppe M, Grift RE, Rijnsdorp AD (2007) Changes in the spatial distribution of North Sea plaice (Pleuronectes platessa) and implications for fisheries management. J Sea Res 57(2-3):187-197. doi:10.1016/j.seares.2006.09.002
Ziegelmeier E (1970) Über Massenvorkommen verschiedener makrobenthaler Wirbelloser während der Wiederbesiedlungsphase nach Schädigungen durch "katastrophale" Umwelteinflüsse. Helgoländer wiss Meeresunters 21:9-20

Zühlke R, Alsvag J, de Boois I, Cotter J, Ehrich S, Ford A, Hinz H, Jarre-Teichmann A, Jennings S, Kröncke I, Lancaster J, Piet G, Prince P (2001) Epibenthic diversity in the North Sea. Senckenb Marit 31:269-281 